\title{
The working for water programme: evolution of a payments for ecosystem services mechanism that addresses both poverty and ecosystem service delivery in South Africa
}

\author{
J.K. Turpie ${ }^{a}$, C. Marais ${ }^{b}$, J.N. Blignaut ${ }^{c}$ \\ ${ }^{a}$ Percy Fitzpatrick Institute, University of Cape Town, Rondebosch, 7701, South Africa \\ ${ }^{b}$ Working for Water Programme, Department of Water Affairs and Forestry, Private Bag X4390, Cape Town 8000, South Africa \\ ${ }^{c}$ Department of Economics, University of Pretoria, Pretoria 0001, South Africa
}

\begin{abstract}
A B S T R A C T
A payments for ecosystem services (PES) system came about in South Africa with the establishment of the government-funded Working for Water (WfW) programme that clears mountain catchments and riparian zones of invasive alien plants to restore natural fire regimes, the productive potential of land, biodiversity, and hydrological functioning. The success of the programme is largely attributed to it being mainly funded as a poverty-relief initiative, although water users also contribute through their water fees. Nevertheless, as the hydrological benefits have become apparent, water utilities and municipalities have begun to contract WfW to restore catchments that affect their water supplies. This emerging PES system differs from others in that the service providers are previously unemployed individuals that tender for contracts to restore public or private lands, rather than the landowners themselves. The model has since expanded into other types of ecosystem restoration and these have the potential to merge into a general programme of ecosystem service provision within a broader public works programme. There is a strong case for concentrating on the most valuable services provided by ecosystems, such as water supply, carbon sequestration, and fire protection, and using these as 'umbrella services' to achieve a range of conservation goals. The future prospects for expansion of PES for hydrological services are further strengthened by the legal requirement that Catchment Management Agencies be established. These authorities will have an incentive to purchase hydrological services through organisations such as WfW so as to be able to supply more water to their users.
\end{abstract}

Keywords:

Working for Water ; Payment mechanisms ; Ecosystem services ; Water supply ; Poverty relief

1. Introduction

South Africa is richly endowed with biodiversity, much of which lies outside of the approximately $6 \%$ of land area that falls within its protected area system. As poverty and the demand for land for urban and agricultural use increase, habitats-and therefore biodiversity - are increasingly under threat. These pressures are further exacerbated by climate change, particularly its impacts on water resources (Turpie et al., 2004). Conservation in South Africa has historically been perceived as a luxury and the concern of the wealthy, especially since almost all conservation efforts are focused on the protected areas, which tend to be geographic, economic, and sociopolitical enclaves. Conservation therefore enjoys a low priority in relation to other more pressing social issues on the political agenda. There is pressure to utilise land and water resources as opportunities for economic development, sometimes in direct conflict with conservation goals. This has serious implications for the future health of terrestrial and aquatic ecosystems and their capacity to deliver goods and services that also contribute to social and economic welfare. Recognising this, there has been considerable effort to describe biodiversity values and the socio-economic impacts of ecosystem degradation (e.g. Turpie, 2003; Turpie et al., 2003). This may justify conservation efforts, but does not guarantee an improvement in the allocation of scarce government resources to conservation in South Africa. Indeed, more pragmatic solutions will need to be found to ensure adequate conservation of biodiversity, and to sustain the values derived from ecosystems in South Africa.

With dwindling government support for conservation within and outside protected areas, there is increasing pressure to find innovative and sustainable solutions for promoting and financing conservation. Payments for ecosystem services (PES) is a mechanism that could play a key role in achieving conservation goals and sustaining ecosystem health more generally. A PES system involves voluntary payments for well-defined ecosystem services (or land uses that are likely to secure those services) that are conditional on service delivery (Wunder, 2005). The transaction involves at least one buyer and one service provider, although there can be a number of each, and the buyers or sellers maybe private individuals, companies, non-government organisations, or the state. PES has an advantage over many other conservation tools in that it is both an incentive and a financing mechanism, and is potentially very efficient (Pagiola et al., 2002; Pagiola and Platais, 2007). Thus targeted conservation areas may benefit from PES as long as conservation action results in a measurable increase in the provision of ecosystem services that can be commodified' and traded. 
The international literature on PES shows that most examples that are actually working are either for carbon or water (Landell-Mills and Porras, 2002; Pagiola and Platais, 2007). While carbon is a viable option, this paper concentrates on the role of water in improving biodiversity conservation through PES in South Africa. Here we argue that water has the potential to be an 'umbrella service' to other ecosystem services, in that efforts to better manage and conserve water in mountain catchments (watersheds) and riparian zones result in the conservation of other services provided by the improved health of the ecosystem. This is very much like efforts to conserve umbrella species also helping conserve other species in their habitat. We examine the unique way in which PES has emerged in South Africa through the establishment of the government's Working for Water (WfW) programme, and the way in which the new Water Act has paved the way for future development and expansion of this financing system. We examine possible ways that the South African situation may develop into a model which could be valuable in developing countries generally.

\section{Water as a key commodity for PES in South Africa}

\subsection{Water scarcity}

South Africa is a chronically water stressed country with between $500 \mathrm{~m}^{3}$ and $1000 \mathrm{~m}^{3}$ of water available per person per year (Ashton, 2002). Surface water is heavily committed for use, water is imported from neighbouring countries, and the limited groundwater resources do not offer much reprieve (Scholes, 2001). As a result, water availability is predicted to be the single greatest and most urgent development constraint facing South Africa. The need for water is further highlighted by the fact that water scarcity in developing countries is closely linked to the prevalence of poverty, hunger, and disease (Falkenmark, 1994; Ashton and Haasbroek, 2002).

Historically, water resource managers met rising water demands through a complex system of engineering supplyside solutions which included major inter-basin transfer and water pumping schemes, even over mountain ranges and across vast distances (Smakhtin et al., 2001). Due to the increasing costs associated with supply-side measures and the limited remaining exploitable water resource potential, these solutions are becoming less viable. This is underlined by the fact that 12 of South Africa's 19 water catchment areas are in deficit and receive water through inter-basin transfers schemes from the remaining surplus areas (Blignaut and de Wit, 2004). It has therefore become necessary to explore other solutions to augment and conserve water supplies (Ashton and Seetal, 2002).

The increasing scarcity of water has made it a highly tradable commodity. It follows that ecosystem services that affect water supply will also become valuable, and ultimately tradable. Indeed, a large proportion of the existing PES systems around the world involve hydrological services such as water regulation (e.g. maintenance of dry season flows). Wherever catchment health affects water supply, and water is scarce, there is a potential market for conservation activities in the catchment. In South Africa, the provision of water is highly dependent on the conservation of catchment areas (watersheds), riparian zones, and wetlands. Most of South Africa's surface water originates from high altitude grassland areas dominated by the Drakensberg Mountains (including the adjacent Maloti Mountains of Lesotho), and in the Cape Mountains that are clad in short, heath-like, Fynbos vegetation (Fig. 1).

\subsection{Threats to water supply}

In the grassland catchment areas, seepage wetlands act as sponges that catch much of the summer rainfall. The slow subsequent release of the infiltrated water serves to maintain base flows in the catchments during the dry season. The functionality of these grassland wetlands is compromised by bad management practices such as overgrazing and inappropriate burning regimes, as well as by damming and reclamation of wetlands.

More serious is the increasing (albeit controlled) tendency for conversion of grassland by afforestation with alien Pinus and Eucalyptus species, which negatively affects the quantity of catchment runoff. These plantations intercept stream flow, especially when close to watercourses.

In addition, base flows are also intercepted by alien vegetation that has invaded stream courses. In the Drakensberg Mountains, invasion by alien plants such as bramble is linked to the degree of afforestation (Turpie et al., 2007). In the Cape Mountain and river systems, infestation by alien invasive plants that escaped from commercial plantations and woodlots on farms - particularly Pinus, Acacia and Eucalyptus species-results in reductions in runoff. The alien invasive plants species swamp the indigenous vegetation, their relatively high biomass resulting in much higher rates 


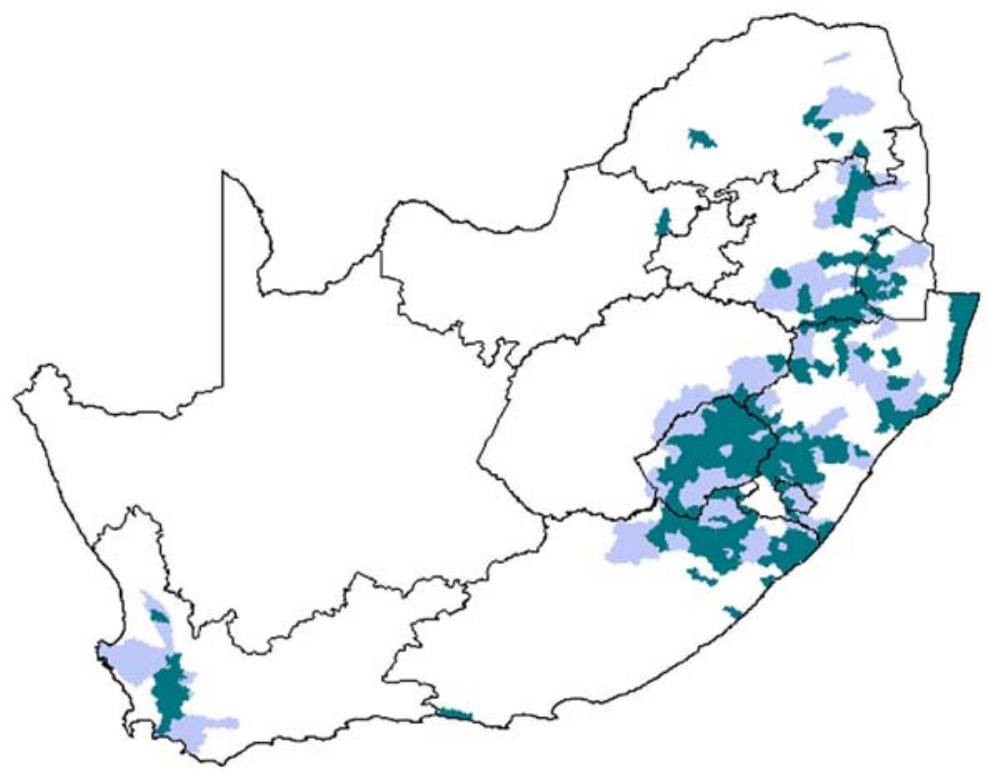

Fig. 1-Areas of high water yield. Source: Driver et al., 2004.

of evapotranspiration. Alien plants have invaded an estimated 10 million ha of South Africa. The Western Cape is the most heavily invaded at about a third of the total area, followed by Mpumalanga, KwaZulu-Natal, and Northern Province (Le Maitre et al., 2000). A detailed survey of the Western Cape mountain catchments showed that around 60,500 out of 1,138 million hectares (ha) (5\% of the total surface area) had an invasion density of at least $25 \%$ (Marais, 1998). Initial estimates are that approximately $54 \%$ of all riparian areas also have an invasion density of at least $25 \%$, or, effectively, some 460,000 ha (Versveld et al., 1998; Cullis et al., 2007). Although this means higher storage of carbon, it is important to note that the majority of these invasive alien plants are also fire-prone or fire dependent.

The invasion of river courses and of important catchment areas is particularly problematic in terms of streamflow reduction (Versveld et al., 1998). A number of studies have demonstrated that alien plants have a measurable negative effect on stream flow (Le Maitre et al., 1996; Scott and Smith, 1997; Baskin, 1996; Van Wilgen et al., 2001; Gorgens and van Wilgen, 2004). The level of streamflow reduction has been quantitatively linked to the vegetation type and density of invasive plants. Le Maitre et al. (2000) estimated the total incremental water use of invading alien plants (i.e. the additional water use compared with the natural vegetation) at about 3,300 million $\mathrm{m}^{3}$ of water per year. Primary catchments in the Western Cape had the greatest reduction, of up to 31\% of mean annual runoff (Le Maitre et al., 1996, 2000). Cullis et al. (2007) estimate that the current loss of usable water due to invasive alien plants is $695 \mathrm{million}^{3}$, equivalent to $4 \%$ of the total registered water use. If left unchecked, this could increase to more than $2,720 \mathrm{million}^{3}$, or $16 \%$ of total registered water use (Table 1). Given the scale of the existing impact and the fact that it continues to increase as the extent and density of the invasions increases, a national control programme is essential if the country's water resources are to be protected.

\subsection{The restoration process}

The control of invasive alien plants involves both manual clearing and the release of biological control agents. Ongoing research and releases of organisms address the latter, but will not replace the need for physical clearing until all the most important species are under biological control and are in significant decline. Meanwhile, physical clearing is the most costly form of restoration. It involves the removal of trees with saws and chainsaws, chemical treatment, and returning to the same site several times over the five subsequent years to remove new growth. In many instances, tree removal involves accessing mountainous areas with climbing ropes, requiring additional skill and cost. The initial clearing cost is very high (as much as 7000 Rand per ha for densely infested areas) (R6.50-7.50: US\$1), but the costs of subsequent follow-up efforts decrease with each treatment. As long as seedbanks remain or there are nearby seed sources from invasive ornamental trees, windbreaks, or plantations, maintenance must be on-going, but costs are very low (less than R50 per ha per treatment which could be at intervals of 1-3 years depending on the species in question) if carried out regularly. After clearing, indigenous vegetation is able to colonise from existing seedbanks. The recovery is usually relatively rapid (within a decade) because of the vegetation types involved. For example, Fynbos is adapted to recovering from regular fire. 
Table 1-Impact of water use by invading alien plants on mean annual runoff in primary catchment areas of South Africa (including Lesotho)

\begin{tabular}{|c|c|c|c|c|}
\hline \multirow[t]{2}{*}{ Primary river system } & $\begin{array}{l}\text { Natural mean annual } \\
\text { runoff }\end{array}$ & $\begin{array}{c}\text { Condensed invaded } \\
\text { area }^{\mathrm{a}}\end{array}$ & $\begin{array}{c}\text { Incremental water } \\
\text { use }\end{array}$ & Water use \\
\hline & $\left(\right.$ million $\mathrm{m}^{3}$ ) & (ha) & (million $\mathrm{m}^{3}$ ) & $\begin{array}{c}\text { (\% of mean annual } \\
\text { runoff })\end{array}$ \\
\hline Limpopo & 2,382 & 122,457 & 190 & 8.0 \\
\hline Olifants & 2,904 & 217,855 & 290 & 10.0 \\
\hline Vaal & 4,567 & 64,632 & 191 & 4.2 \\
\hline Orange & 7,148 & 141,012 & 141 & 2.0 \\
\hline Olifants, Sout and Doring & 1,008 & 37,623 & 36 & 3.5 \\
\hline Namaqualand coast & 25 & 46,618 & 23 & 91.0 \\
\hline W Cape and Agulhas coast & 2,057 & 384,636 & 647 & 31.4 \\
\hline Breede and Riversdale coast & 2,088 & 84,398 & 182 & 8.7 \\
\hline Gouritz & 671 & 59,399 & 75 & 11.2 \\
\hline S Cape coast & 1,297 & 52,993 & 134 & 10.4 \\
\hline Gamtoos & 495 & 34,289 & 97 & 19.5 \\
\hline $\begin{array}{l}\text { PE Coast, Swartkops and } \\
\text { Coega }\end{array}$ & 150 & 11,358 & 40 & 26.8 \\
\hline Sundays & 280 & 3,964 & 8 & 3.0 \\
\hline $\begin{array}{l}\text { Bushmans and Alexandria } \\
\text { coast }\end{array}$ & 173 & 22,894 & 73 & 42.3 \\
\hline Gt Fish & 521 & 6,980 & 21 & 4.1 \\
\hline Border Coast & 579 & 12,483 & 56 & 9.6 \\
\hline Great Kei & 1,042 & 30,694 & 138 & 13.3 \\
\hline Former Transkei & 7,384 & 68,493 & 217 & 2.9 \\
\hline S KwaZulu-Natal & 3,121 & 46,442 & 126 & 4.1 \\
\hline Tugela & 3,991 & 62,151 & 105 & 2.6 \\
\hline N KwaZulu-Natal & 4,742 & 100,574 & 230 & 4.9 \\
\hline Komati to Nwanedzi & 2,871 & 124,494 & 283 & 9.9 \\
\hline Total & 49,496 & $1,736,438$ & 3,303 & 6.7 \\
\hline
\end{tabular}

The Conservation of Agricultural Resources Act (CARA), promulgated in 2005, makes landowners liable for clearing invasive alien plants from their lands. However, the reality is that due to the high costs involved, landowners are not able to comply unless the level of infestation is very low. To date the act has simply not been enforced, while in some cases government has supported landowners to clear invasions through the WfW programme. In any case, it is debatable whether making landowners responsible for past invasion is equitable (Turpie, 2004).

\section{The Working for Water Programme}

\subsection{Background}

Payments for Ecosystem Services in South Africa have largely come about through the establishment of the Working for Water (WfW) programme in 1995. This government programme was initiated in response to the realisation of the gravity of the threat that alien plants posed to water supplies. A group of natural resource managers and scientists presented the idea of the programme to the then Minister of Water Affairs and Forestry, Prof. Kader Asmal, of the newly elected African National Congress (ANC) government, in 1995. They proposed addressing two immediate challenges with one intervention: clearing invasive alien plants could not only address the effect of invasive alien plants on the country's scarce water resources, but also had considerable potential for job creation and economic empowerment.

Today, WfW is a public agency under the jurisdiction of the Department of Water Affairs and Forestry (DWAF) with the mandate of controlling invasive alien plant infestation. What is particularly unusual about the programme is that it was initiated and is funded primarily as a poverty relief public works programme. This is reflected in its goal of sustainably controlling invasive alien species by 2020 "in order to contribute to economic empowerment, social equity and ecological integrity" (DWAF, 2004). 
Table 2 - Funding for the Working for Water Programme, 1995-2006 ('000 Rand)

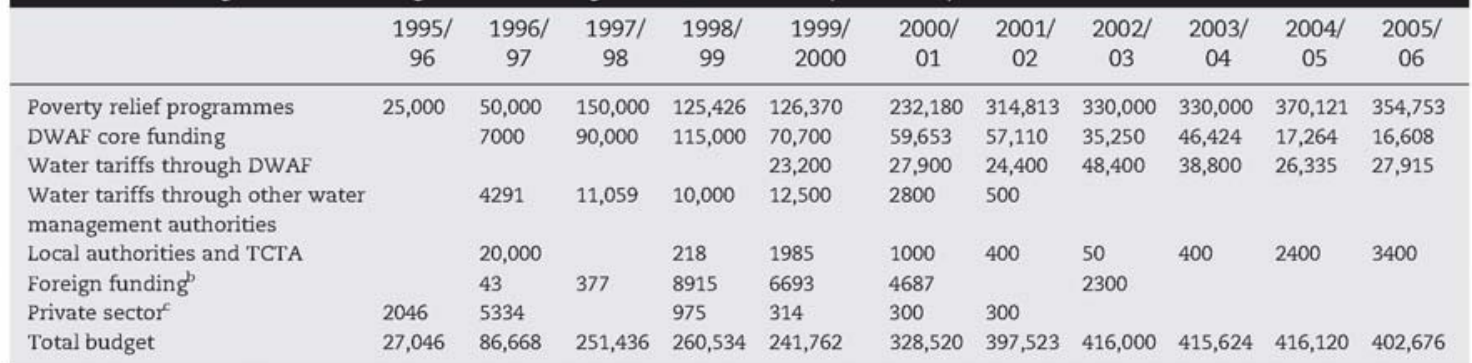

Source: Working for Water, unpublished data.

"Initial partnership with Rand Water (the water management agency for the greater Johannesburg metropole) came to an end without a new partnership being negotiated.

${ }^{b}$ From Finish and Norwegian governments.

'Formal funding partnership with the private sector agencies came to an end; clearing by private sector companies is still on-going but not reported on.

As shown in Table 2, the WfW programme has an annual budget of more than R400 million (RSA, 2003) - the largest single natural resource based poverty relief and public works expenditure in the country. In comparison, the government's total expenditure on all national and provincial parks and related activities in 2001/2002 was R728 million (RSA, 2003). The bulk of the funding over the last 11 years has been generated through poverty relief programmes (the Reconstruction and Development Programme, then the Special Public Works Programmes, which evolved to become the Expanded Public Works Programme). The poverty relief programmes are funded in clusters. WfW forms part of the Environmental and Social Cluster. DWAF has also contributed substantial amounts to the programme, using funding allocated to the Department by the National Treasury from tax revenue. The National Treasury allocates budgets are allocated to the departments responsible for programmes in three-year cycles, known as Medium Term Expenditure Frameworks (MTEF). Budgets are based on three main criteria: the functional priority (e.g. water conservation, biodiversity, productive potential of land), the impact on poverty relief and economic empowerment, and the department's capacity to spend the budget effectively and efficiently. Some international aid funding was raised of WfW during its early years, but although it played a catalytic role it made up only a small proportion of the total budget. Water management agencies also entered into formal partnerships with WfW under which they contributed to funding the programme. DWAF's water trading account (funds raised from water charges) provided another source of income, as discussed in the next section. The funding from this source is focussed on the control of invasive alien plants with acknowledged negative impacts on water resources (DWAF, 2007). For some years WfW reported matching funding spent by the forestry industry through an informal partnership through Forestry South Africa (a nongovernmental agency representing commercial forestry). Since the partnership came to an end, the programme has not recorded this expenditure, although private sector companies continue to clear. Likewise, other sources of funds come and go for various reasons, but they remain minor contributors.

WfW effectively acts as a conduit for the provision of ecosystem goods and services, predominately water supply, through the control of invasive alien plants and the provision of unskilled job opportunities, using predominantly taxpayers' money. Whether this is justifiable in terms of the spread of the taxpayers versus the beneficiaries of clearing is uncertain, although it should be noted that water savings in one area have geographically widespread ramifications, and biodiversity benefits are also likely to have more than localised benefits. Though this form of transfer payment does not constitute the creation of a market for the provision of ecosystem goods and services in the strict sense, it does constitute a payment for the service delivery. While much of the earlier work has been done exclusively within national and provincial parks, most (66\%) of WfW's activities over the latter years (2001-2006) was outside of these conservation enclaves, contributing greatly to conservation and ecosystem health on unprotected land.

\subsection{Mandatory payments by water users}

The DWAF includes a water resource management fee in the water tariff charged to consumers. The water charge levied for catchment management does not distinguish between richer and poorer consumers per se, but it is superimposed on a stepped pricing system that does. Water resource management charges include a charge for the control of invasive alien plants as well as charges for activities such as planning and implementation, pollution control, demand management, water allocation and water use control. In the past, charges for clearing of invasive aliens were 
levied in 13 of the country's 19 Water Management Areas (WMAs). The aim is to extend this to all 19 water management areas as some of the most stressed catchments have not yet been included.

Once fully operational, the charges levied will be based on WfW's cost estimates, divided by the total volume of registered water use by the agricultural, domestic and industrial sectors, weighted according to affordability, assurance of supply and equity (see also Blignaut et al., 2007). Initially, only domestic water users were fully charged, while agriculture received a substantial subsidy and the forestry sector did not contribute anything, both due to affordability considerations. This practice is likely to change in the future as the impacts of invasive alien plants become clearer. A total of between R23 million and R48 million per annum was allocated from funds raised through DWAF's water tariffs (Table 2). Most (63\%) of this is generated in the four Western Cape WMAs (16-19) where the problem of alien infestation in relation to water supply is greatest.

\subsection{Voluntary payments by water users}

Certain municipalities have entered into payment agreements with WfW to alleviate localised water shortages. In 1996 the municipality of Hermanus, a coastal resort town in the Western Cape, responded to critical water shortages by introducing a block rate tariff system for water that effectively raised water prices for users above other areas. Its main motivation was water demand management, since increasing demand was outstripping supply. A significant percentage of the revenues collected were paid to WfW for clearing invasive alien plants in the catchment areas from which Hermanus derives its water. Water consumers participated in developing this arrangement. The formal arrangement with the local authority continued until 2001. While the arrangement was in place, WfW treated 3387 ha (763 ha if condensed to $100 \%$ infestation) in the catchment of the De Bos Dam, the reservoir supplying Hermanus with water, at a contracting cost of R2.7 million with an estimated total cost of R4.9 million (including project management costs and all other overhead costs), generating 91 person years of employment. Using Cullis et al. 's (2007) very conservative estimates of the impacts of invasive alien plants in mountain catchments, it is estimated that this action prevented losses of between 1.1 and 1.6 million $\mathrm{m}^{3}$ annually. Since 2001, the local authority has contracted teams directly to continue the control of invasive alien plants.

Also in the Western Cape, the George municipality has recently embarked on a new augmentation scheme to supplement the capacity of the Garden Route Dam. After studying the impacts of invasive alien plants on water supply, George concluded that investing in a clearing programme to enhance water supply was economically viable. George municipality has thus recently committed to payments of R400.000 per year for clearing invasive alien plants in the Outeniqua Mountain Catchment Area, either through WfW, or through the Western Cape Nature Conservation Board, which manages the mountain catchment area. The amount is collected through the trading account of the DWAF and is shown as such in Table 2.

Water utilities are financially autonomous and publicly owned companies that supply water to urban users in South Africa. Some of these utilities (e.g. Umgeni Water, the largest bulk water supplier in KwaZulu-Natal province) have established contracts with WfW to ensure the continuity of their water supplies. In the Western Cape, the Trans Caledon Tunnel Authority (TCTA) is responsible for the implementation and funding of the R1.6 billion (\$250 million) Berg Water Project, which entails the construction of the Berg River Dam to supply water to local farmers and the City of Cape Town. The project will be funded through water sales. This company concluded that payments for ecosystem services would be a worthwhile economic investment and signed a contract to pay R8 million to WfW over three years to clear the mountain catchment areas that will supply the Berg River Dam. To date some R11.6 million has been spent on the project, of which TCTA contributed an estimated R8.4 million, clearing an area of 13,200 ha. The annual longterm streamflow gains from clearing the current levels of invasion in the treated area, based on Cullis et al. (2007), are between 1.8 and 2.6 million $\mathrm{m}^{3}$. On the other hand, if nothing had been done and invasions had been allowed to increase to $100 \%$ infestation, water losses could have increased to between 4.3 and 6.2 million $\mathrm{m}^{3}$ per annum.

\section{Characteristics of the WfW programme}

According to Wunder's (2005) definition, PES is a voluntary transaction between two parties. Even after 10 years of operation, only a small proportion of WfW's funding comes from voluntary payments, although this proportion is likely to grow. DWAF's draft Water Pricing Strategy states that the full cost of controlling certain invasive alien plants (using the most cost effective possible action) maybe charged to affected water users in order to increase long-term water security (DWAF, 2007), although these costs may also be supported by subsidy where available and appropriate. It also states that the cost of control will be allocated to all water user sectors that are willing to participate, in proportion to their registered water abstraction, and that these sectors will receive the resultant additional water (DWAF, 2007). The latter suggests an element of voluntariness, at least at the sectoral level.

As demand for water grows, there is the potential for moving from a system that is highly dependent on government funding to one based, at least in part, on voluntary transactions. This potential is demonstrated by the voluntary 
agreements that have been entered into to date, as well as by the expressed willingness of consumers to participate where they have been consulted. As the role of Catchment Management Agencies (CMAs) increases (see section 8 below), the incentives to enter into such voluntary arrangements with WfW and similar service providers are likely to increase.

In most PES systems, the sellers are landowners, whether state, private, or communal. In this case, the 'sellers' are roving service providers in the form of small-scale contractors who perform restoration work on land under any type of ownership. The seller selection criterion is that contractor staff must have been previously unemployed. Like some PES systems, where landowners bid to participate as service providers, potential contractors tender to win contracts. Contracts specify how invasive alien plants in a defined area are to be treated, either chemically, mechanically, or both, depending on the species and maturity of the stand.

The landowners involved in the transaction include private landowners, communal landowners, and the state (in the case of protected areas). Private and communal landowners are mainly farmers, and typically use the affected areas as rangelands and to harvest natural resources, such as wild flowers and thatch (roofingmaterial) for either commercial or subsistence purposes. Private and communal landowners benefit from having their land cleared through increased productivity, but the cost of clearing is too high to make it worthwhile from a private perspective (Turpie and Heydenrych, 2000; Turpie et al., 2003), even though they are obliged to do so by law. Most WfW projects are on public lands, but some projects are on communal or private lands, usually in important conservation areas. In the latter cases the landowners do not bear any costs.

Another unique feature of this programme is that the cost of intervention is relatively low. This is unlike most other PES systems where conservation action carries a significant and on-going opportunity cost, typically as a result of decreased agricultural or forestry production from the lands in question. In this case, total costs are low because (1) no land use is displaced, and in fact treated land (if used for agriculture or natural resource harvesting) is likely to be more productive, so the opportunity cost portion of the total cost is low or even negative; and (2) labour costs are low from society's perspective as the labour employed has few alternative formal sector employment opportunities. This leaves materials costs (equipment, travel to sites, etc) as the major costs.

With low costs, the programme has the luxury of being able to prioritise areas for action using ecological and social rationales. Site selection has been relatively ad hoc in the past, based on catchments that were perceived to be priority areas for clearing. There are plans to use an ecologically based cost-benefit analysis tool developed by Marais et al. (2001) to increase the economic efficiency of site prioritisation. However the tool's data intensity and the lack of economic data, such as nature based and ecotourism and veld and forest fire management costs, makes it relatively expensive to do.

\section{Achievement of programme objectives}

The WfW programme has been hailed as highly successful in terms of its objective of restoring water supply in alieninfested catchments (Macdonald, 2004). Hobbs (2004) calls it one of the most successful integrated land management programmes in the world, referring to the programme's impacts on biodiversity, water and socio-economic development. Mooney and Neville (2000) described the programme as an outstanding example of dealing with invasive alien plants in a holistic manner. Wood-worth (2006) calls it inspirational in terms of the restoration of natural capital. Since its inception, the programme has cleared more than one million ha of invasive alien plants. Marais and Wannenburgh (2007) estimate that the clearing of invasive alien plants from riparian areas between 1997 and 2006 increased stream flow by nearly 46 million $\mathrm{m}^{3}$ per annum. Whereas costs have been very well monitored, progress in terms of restoration of infested lands has not been tracked in detail until the establishment of GIS-linked monitoring in 2000/01. Based on available data, it has been established that good progress has been made with certain species, but that some will not be under control within the next 50 years (Marais et al., 2004).

While many PES programmes include the objective of poverty alleviation as a side objective, it is the one of the primary objectives of WfW. Indeed, the continued political support of the programme has hinged on its being primarily a poverty-relief programme. The programme has created thousands of jobs, with a strong emphasis on gender equity, and provides considerable benefits such as skills training and health and HIV/ AIDS awareness programmes. For example, Milton et al. (2003) estimate that 24,000 previously unemployed people, 52\% of whom are women, were employed in 2000. It also generates further income through the development of value adding industries, such as furniture, fuel wood, and charcoal that use alien vegetation as inputs.

Although the social aspects of WfW tend to be valued more highly than water provision, it is likely increasing water scarcity will lead to the water provision aspects being increasingly demanded by the private sector and water utilities. Indeed, if the programme continues to rely heavily on poverty relief funding, it might find itself having to compete 
with other poverty relief programmes in the future. It is important to increase payments from service users to secure the continuation of service delivery. Nevertheless, given the scale of the invasive alien species problem facing South Africa, and the increasing scientific proof of its benefits (water delivery and biodiversity protection) provided by clearing action, the WfW-model is likely to be sustainable and productive over the long term.

\section{6. $\quad$ Expanding the Working for Water model}

The WfW programme has focused primarily on projects that improve water delivery, and not on ecological restoration per se. This inherent shortcoming has spawned two new programmes, Working for Wetlands and Working for Woodlands, which are engaged in restoration of those habitats. The wetlands programme is largely motivated by the impact on biodiversity as well as hydrological services. The woodlands programme is geared towards carbon sequestration services. The Working on Fire initiative is another offspring of the WfW programme: it promotes and is actively involved in the responsible and safe use of fire as an environmental management intervention.

Moreover, even under WfW, the control of invasive alien plants now also takes place in areas where there is no hydrological benefit-for biodiversity conservation or to enhance the productive potential of land. For example, WfW clears Prosopis in the Northern Cape Province primarily to restore the productive potential of grazing lands. Prosopis preferentially invades depressions in the landscape that can have up to four times the grazing potential of upland areas, according to farmers. The capital costs of clearing dense stands of Prosopis are simply unaffordable to land users (around R2000 to R2500/ha for initial clearing alone), where the retail value of the land varies between R600 and RIOOO/ha. In the Eastern Cape Province, invasive Acacias have been cleared from coastal dune systems on state land to make way for the cultivation of indigenous thatching reeds that can yield R60,000-R120,000 per ha every four to six years. WfW plans to recover the cost of clearing by selling the mature thatch. The project, if well managed, would have an internal rate of return of $6.0 \%$ (Kleynhans, 2006). This estimate is conservative as it includes the full cost of clearing but does not include the value of other ecosystem services, such as a reduction in veld fire intensity and its related risk to infrastructure and improvements to biodiversity and the water table. If successful, this project will lead to more selfsustaining natural resource based community development projects being set-up.

Taken together, these developments could be paving the way for the development of an overarching 'Working for Ecosystem Services' organisation that houses nature-oriented (restoration) poverty-relief programmes. The existing model and potentially extended model differ substantially from other PES systems in that restoration is carried out via a contract with individuals other than landowners, and that there is a significant poverty-alleviation component. This is not to say, though, that landowners may not incur opportunity costs. The certainly may in the case of wetland or woodland restoration initiatives.

\section{The rationale for an 'umbrella service' for PES}

The areas of high water provision in South Africa are also the areas that contain very important biodiversity. Indeed both the Drakensberg and Cape mountains are centres of endemism, and the latter form a significant component of the Cape Floral Kingdom, which has been billed as the world's "hottest" biodiversity hotspot (Myers, 1990). Thus, a system that encourages the conservation of catchment areas for water supply will also make an important contribution to habitat maintenance and biodiversity conservation. In this way, we suggest that water provision could be seen as an 'umbrella service', in that initiatives taken to preserve this service would also lead to the conservation of biodiversity and other ecosystem services. In this regard it is interesting to note that, in South Africa, both water and carbon may play this role, but in geographically distinct areas. The high-biomass areas suitable for carbon sequestration through restoration of high-biomass indigenous vegetation types are completely separate from the low-biomass mountainous areas that are important for water provision.

Although it is now well known that ecosystems generate numerous services, such as nutrient cycling, provision of refugia, etc. (Millennium Ecosystems Assessment, 2003), some of these services are inherently more marketable than others. Their marketability lies in their tangibility or measurability, and in the context of PES, the ability to prove that changes in management lead to changes in the output of economically valuable services. Indeed, in PES systems around the world, it has been found that most examples are for a few main commodities, particularly carbon, water, productive potential, biodiversity and landscape beauty, with markets for carbon sequestration and hydrological services being dominant (Landell-Mills and Porras, 2002; Pagiola and Platais, 2007). Among these commodities, Pagiola and Platais (2007) argue that water services have the most potential for application of the PES approach as water users (1) are easy to identify; (2) receive clear, well-defined benefits; and (3) often already have financing mechanisms - none of which is true for biodiversity. Carbon lies somewhere in between. In particular, there are tight overall limits on the emission reduction credits that can be generated by land use-based activities under the Clean 


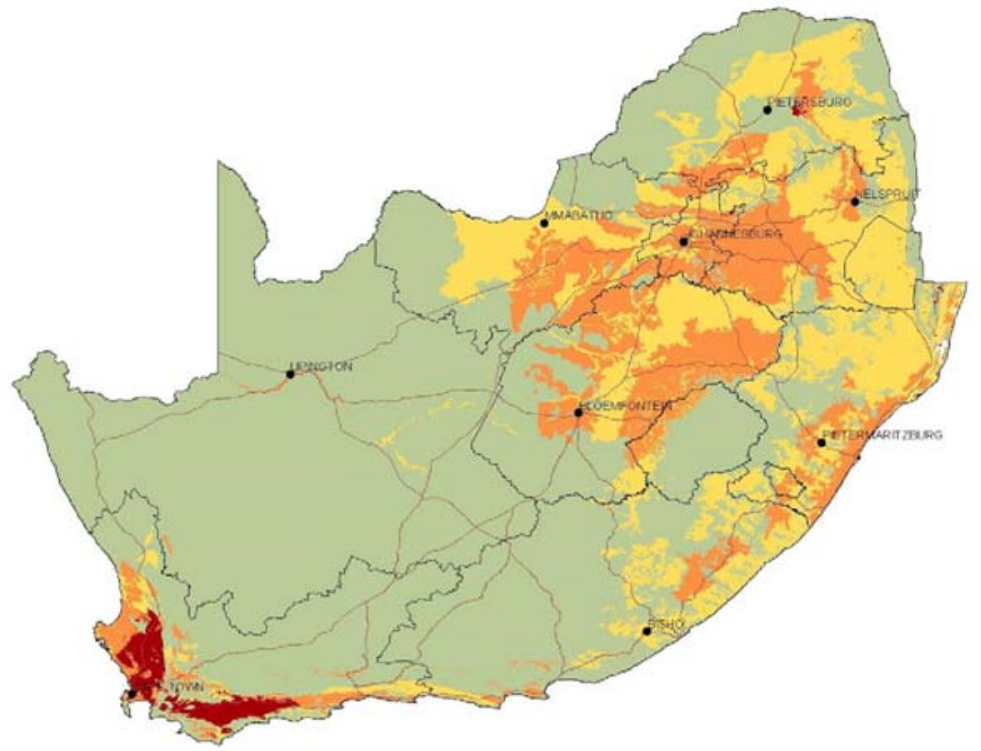

Fig. 2-Critically endangered, endangered and vulnerable ecosystems in South Africa. Source: based on Rouget et al., 2004.

Development Mechanism (CDM) and very restrictive rules on eligibility and methodologies, while the voluntary ('retail') market, though more flexible than the CDM market, is also smaller and tends to pay less.

Marketing the hydrological and climate regulation functions of ecosystem restoration projects has many advantages. They are well understood by the broad populace, making it more likely that willing-buyer and willing-seller combinations can be found. The positive externalities of these projects, such as biodiversity conservation, protection of endemism, nutrient recycling, etc. are therefore 'un-priced' coincidental benefits. Should they, however, be clearly identified, the restoration activity could sell at a premium over projects where these positive externalities are not clearly identified or not present. In this way hydrological and climate regulation restoration programmes become an umbrella for the bundling of various ecosystem services.

It will be pertinent to determine (1) the extent to which the different benefits are correlated with each other, and (2) the extent to which the cost and actions of addressing one benefit also cover that of addressing the others. For example, if biodiversity conservation in a given area requires costs additional to that of improving water supplies, then it would still be necessary to seek separate financing. As shown in Fig. 2, there is certainly extensive, though not complete, overlap between priority catchment areas and areas, which require conservation action in South Africa (Midgley et al., 1994; Rouget et al., 2004).

\section{8. $\quad$ Fitting a WfW type model into a broader PES framework}

The way for introducing PES as a broad-scale conservation tool for achieving both biodiversity conservation and ecosystem service delivery has been paved by the development and evolution of the WfW-model. Indeed, conservation planners in South Africa are currently looking to PES as potentially playing a major role in realising conservation initiatives (e.g. Diedrichs et al., 2004), such as the Cape Action for People and the Environment (CAPE), which has an ambitious conservation plan for the Cape Floristic Region (Cowling et al., 2003), and the Maloti-Drakensberg Transfrontier Project, which is embarking on a conservation plan for the Drakensberg and Maloti Mountains of South Africa and Lesotho (Zunckel, 2003). Invasive alien plant management is seen as one service amongst other natural resource management activities that will constitute the supply side of the PES market in South Africa. The other services will include wetland and riparian restoration (restoration of erosion gullies, etc.) and management, integrated grazing and land use regimes and an integrated veld and forest fire management regime. PES is being seen as an opportunity for (a) sustainable financing of the publicly owned protected areas, or leveraging the management costs of 


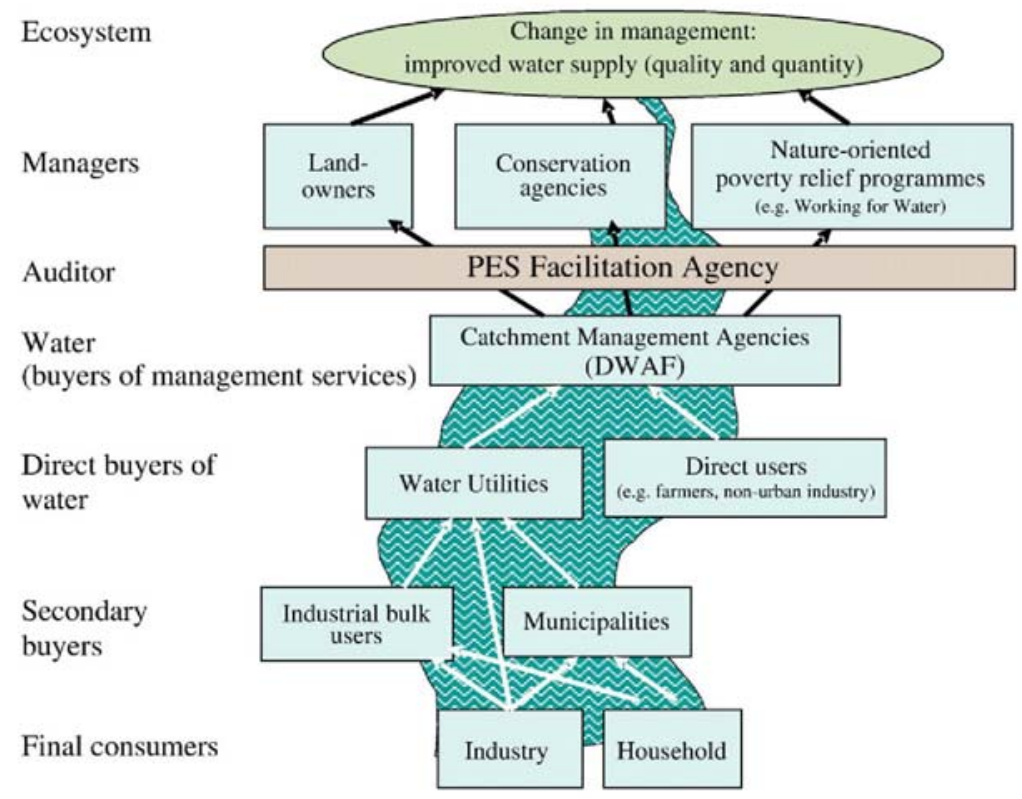

Fig. 3-A potential model for establishment of payments for hydrological services.

these conservation areas into perpetuity, and (b) providing an incentive for private land owners to engage in biodiversity conservation in order to meet conservation targets that cannot be reached by the protected area systems. Although conservation in both areas stands to provide a wide range of benefits in terms of maintenance of biodiversity and ecosystem services, neither meets the necessary criteria for trade in carbon credits, and water is the most valuable ecosystem service in both cases (Turpie et al., 2003, 2007; Turpie, 2004). Indeed, these two areas are the source of most of the water used throughout the country.

Where hydrological functioning can be sold as the 'umbrella service', the future potential for successful implementation of PES has been significantly enhanced by the institutional arrangements that will be established under South Africa's new Water Act (Act 36 of 1998, DWAF, 1998). According to the Act, the CMAs that will be established will effectively 'own' the water and finance catchment management through the sale of water rights. The CMAs will have the incentive to invest in catchment conservation by means of payments to landowners and managers, as well as through management agents such as WfW, as this will yield benefits in terms of more water available to sell. Thus, in addition to the creation of WfW, the legislated requirement to establish CMAs has effectively also paved the way for a very effective institutional arrangement to facilitate water-related PES in South Africa.

Based on these existing structures, we envisage a future model for water-related PES in which the CMAs are the direct buyers of hydrological services, via a type of PES facilitation agency that brokers deals, and monitors service delivery (Fig. 3). The service providers might be predominantly nature-oriented poverty-relief programmes such as WfW, but could also include landowners and conservation agencies directly. Under this type of set-up, there is no need to impose specifically labelled levies to be paid by water consumers for catchment conservation, although the costs borne by the CMAs would be passed on to these consumers. A further advantage of such a system is the fact that water price increases could be designed in such a way as to achieve water demand management in addition to the conservation of catchment areas.

\section{Conclusions}

Whereas links between ecosystem quality and service delivery have seldom been quantified in physical terms, South Africa presents a fairly unusual case in that the relationship between ecosystem quality and water yield are very well understood. Because of the increasing scarcity of water in South Africa, there has been a high level of support of research into the impacts of invasive alien plants on water supply. The quantification of these impacts spawned a 
government-funded effort at clearing invasive alien plants. Although well funded through the tax base and compulsory charges, voluntary private initiatives have also been undertaken to boost the funding to WfW. This is not only testament to the fact that the resultant restoration of water services makes financing WfW worthwhile, but also that there is a potentially large voluntary market for these services. The fact that delivery of these services is labour intensive and provides opportunities for poverty relief makes it even more attractive.

The restoration and protection of catchments to improve water yields also leads to the conservation of biodiversity, a benefit that is more difficult to commodify and sell. The same is potentially true for the restoration of woodlands and thicket for carbon sequestration. With this rationale in mind, major conservation initiatives in South Africa are looking to PES systems, mainly for water, as potential financing mechanisms. With the existence of WfW and its related programmes, and the legislative environment regarding the control of catchment water resources, it will be possible to implement these systems with little need for major innovations or institutional reform.

The key challenges that lie ahead include increasing the voluntary payments for hydrological services, identifying ways to monitor changes in service delivery, and linking payments to service delivery. It is also important to improve understanding of the relationships between management actions and service delivery for a broader range of situations than the clearing of alien invasive plants, such as the implications of wetland restoration for water yield.

\section{Acknowledgements}

We are grateful to the participants of the Workshop on Payments for environmental services: Methods and design in developing and developed countries, held in Titisee, Germany, in June 2005, for their feedback, and to Stefano Pagiola, Sven Wunder, Nicola King and two anonymous referees for their comments on earlier drafts. This paper does not necessarily represent the official view of the employers of any of the three authors.

\section{R E F E R E N C E S}

Ashton, P.J., 2002. Avoiding conflicts over Africa’s water resources. Ambio 31, 236-242.

Ashton, P.J., Haasbroek, B., 2002. Water demand management and social adaptive capacity: a South African case study. In: Turton, A.R., Henwood, R. (Eds.), Hydropolitics in the Developing World: A Southern African Perspective. African Water Issues Research Unit (AWIRU) and International Water Management Institute (IWMI). 24 pp.

Ashton, P.J., Seetal, A., 2002. Challenges of water resource management in Africa. African Renais-Science Conference, Durban, 1215 March. Baskin, Y., 1996. Curbing undesirable invaders. BioScience 46, 732-737.

Blignaut, J.N., De Wit, M.P. (Eds.), 2004. Sustainable options. UCT press, Cape Town.

Blignaut, J.N., Marais, C, Turpie, J.K., 2007. Determining a charge for invasive alien plant species (IAPs) to augment water supply in South Africa. Water SA 33, 27-34.

Cowling, R.M., Pressey, R.L., Rouget, M., Lombard, AT., 2003. A conservation plan for a global biodiversity hotspot: the Cape Floristic Region, South Africa. Biological Conservation 112, 191-216.

Cullis, J.D.S., Gorgens, A.H.M., Marais, C, 2007. A strategic study of the impact of invasive alien plants in the high rainfall catchments and riparian zones of South Africa on total surface water yield. Water SA 33, 35-42.

Diederichs, N, Mander, M., Blignaut,]., Turpie, J.Jewitt, G., Shafer, W., Markewicz, A., O'Connor, T., Mavundla, H., Murphree, M., 2004. Payment for ecosystem services baseline study. Unpublished report for the Maloti Drakensberg Transfrontier Project.

Driver, A., Maze, K., Lombard, AT., Nel, ]., Rouget, M., Turpie, J.K., Cowling, R.M., Desmet, P., Goodman, P., Harris, H., Jonas, Z., Reyes, B., Sink, K., Strauss, T., 2004. National Spatial Biodiversity Assessment National Spatial Biodiversity Assessment 2004: Priorities for Biodiversity Conservation in South Africa. Strelitzia 17. South African National Biodiversity Institute, Pretoria. 44 pp.

DWAF, 1998. National Water Act for South Africa. Department of Water Affairs and Forestry, Pretoria.

DWAF, 2004. The Working for Water Programme: Annual Report 2002/3. Department of Water Affairs and Forestry, Pretoria.

DWAF, 2007. Establishment of a pricing strategy for water use charges in terms of section 56(1) of the National Water Act, 1998. Department of Water Affairs and Forestry, Pretoria.

Falkenmark, M., 1994. The dangerous spiral: near-future risks for water-related eco-conflicts. Proceedings of the ICRC Symposium Water and War: Symposium on Water in Armed Conflicts, International Committee of the Red Cross, Montreux, Switzerland, 2123 November. 16 pp.

Gorgens, A.H.M., Van Wilgen, B.W., 2004. Invasive alien plants and water resources in South Africa: current understanding, predictive ability and research challenges. South African Journal of Science 100, 27-34.

Hobbs, R.J., 2004. The Working for Water Programme in South Africa: The science behind the success. Diversity \& Distributions 10, 501-503.

Kleynhans, T.E., 2006. An investigation of the financial-economic viability of the St. Francis Bay Thatch Reed Production Project. Report II of A Market Analysis of the Thatch Market in South Africa and the replication ability of the Working for Water St. Francis Thatch Project. Unpublished Report for the Department of Water Affairs and Forestry.

Landell-Mills, N, Porras, I., 2002. Silver bullet or fools' gold? A Global Review of Markets for Forest Environmental Services and 
their Impact on the Poor. IIED, London.

Le Maitre, D.C., van Wilgen, B.W., Chapman, R.A., McKelly, D.H., 1996. Invasive plants and water resources in the Western Cape Province, South Africa: modelling the consequences of a lack of management. Journal of Applied Ecology 33, 161-172.

Le Maitre, D.C., Versveld, D.B., Chapman, R.A., 2000. The impact of invading alien plants on surface water resources in South Africa: a preliminary assessment. Water SA 26, 397^108.

Macdonald, I.A.W., 2004. Recent research on alien plant invasions and their management in South Africa: a review of the Inaugural Research Symposium of the Working for Water Programme. South African Journal of Science 100, 21-26.

Marais, C, 1998 An economic evaluation of the invasive alien plant control programmes in the mountain catchment areas of the Western Cape Province, South Africa. PhD dissertation. University of Stellenbosch.

Marais, C, Turpie, ]., Mullins, D., Conradie, B., Khan, A., Goldin, ]., van Zyl, H., Grobbelaar, E., Vink, N, Ndzinge, V., 2001. A cost benefit analysis framework for the national working for water programme. Report to Working for Water.

Marais, C, van Wilgen, B.W., Stevens, D., 2004. The clearing of invasive alien plants in South Africa: a preliminary assessment of costs and progress. South African Journal of Science 100, 97-103.

Marais, C, Wannenburgh, A.M., 2007. Restoration of water resources (natural capital) through the clearing of invasive alien plants from riparian areas in South Africa- costs and water benefits.

Mooney, H., Neville, L., 2000. Addressing the complex problem of invasive species. In: Preston, G., Brown, G., van Wyk, E. (Eds.), Proceedings of South Africa/United States of America Bi-National Commission Conference on Best Management Practices for Preventing and Controlling Invasive Alien Species, Kirstenbosch Botanical Gardens, Cape Town 22-24 February 2000, pp. 141157.

Midgley, D.C., Pitman, W.V., Middleton, B.J., 1994. The surface water resources of South Africa 1990. Volumes 1 to 6. Report Numbers 289/1.1/94 to 298/6.1/94 (text) and 298/1.2/94 to 298/ 6.2/94 (maps), Water Research Commission, Pretoria. Also accompanied by CD-ROM with selected data sets.

Millennium Ecosystem Assessment, 2003. Ecosystems and Human Well Being: A Framework for Assessment Millennium Ecosystem Assessment. Island Press, Washington.

Milton, S.J., Dean, W.R.J., Richardson, D.M., 2003. Economic incentives for restoring natural capital in southern African rangelands. Frontiers of Ecology and Environment 1, 247-254.

Myers, N., 1990. The biodiversity challenge: expanded hotspot analysis. The Environmentalist 10, 243-256.

Pagiola, S., Bishop, ]., Landell-Mills, N. (Eds.), 2002. Selling Forest Environmental Services: Market-based Mechanisms for Conservation and Development. Earthscan, London.

Pagiola, S., Platais, G., 2007. Payments for Environmental Services: From Theory to Practice. World Bank, Washington.

Republic of South Africa, 2003. Estimates of National Expenditures. National Treasury, Pretoria.

Rouget, M., Reyes, B.Jonas, Z., Desmet, P., Driver, M., Maze, K., Egoh, B., Cowling, R.M., 2004. South African National Spatial Biodiversity Assessment 2004: Technical Report, vol. 1 Terrestrial Component. South African National Biodiversity Institute, Pretoria.

Scholes, R., 2001. Global Terrestrial Observing System: Regional Implementation Plan for Southern Africa. GTOS-21.

Scott, D.F., Smith, R.E., 1997. Preliminary empirical models to predict reductions in total and low flows resulting from afforestation. Water SA 23,187-200.

Smakhtin, V., Ashton, P.J., Batchelor, A., Meyer, R., Maree, J.P., Murray, M., Barta, B., Bauer, N., Terblanche, D., Olivier, ]., 2001. Unconventional water supply options in South Africa: possible solutions or intractable problems? Water International 26, 314-334.

Turpie, J.K., 2003. The existence value of biodiversity in South Africa: How interest, experience, knowledge, income and perceived level of threat influence local willingness to pay. Ecological Economics 46, 199-216.

Turpie, J.K., 2004. Ecosystem services supplied by the Maloti-Drakensberg Bioregion. Report to FutureWorks for the Maloti Drakensberg Transfrontier Conservation and Development Programme.

Turpie, J.K., Heydenrych, B.H., 2000. Economic consequences of alien infestation of the Cape Floral Kingdom's fynbos vegetation. In: Perrings, C, Williamson, M., Dalmazzone, S. (Eds.), The economics of Biological Invasions. Edward Elgar, Cheltenham, pp. 214-261.

Turpie, J.K., Heydenrych, B.J., Lamberth, S.J., 2003. Economic value of terrestrial and marine biodiversity in the Cape Floristic Region: implications for defining effective and socially optimal conservation strategies. Biological Conservation 112, $233-251$.

Turpie, J.K., O'Connor, T., Mills, A., Robertson, H., 2007. The ecological and economic consequences of changing land use in the southern Drakensberg grasslands, South Africa. Southern African Journal of Economic and Management Sciences 10, 423-443.

Turpie, J.K., Winkler, H., Midgley, G., 2004. Economic impacts of climate change in South Africa: a preliminary analysis of unmitigated damage costs. In: Blignaut, J., de Wit, M. (Eds.), Sustainable Options. UCT Press.

Van Wilgen, B.W., Richardson, D.M., Le Maitre, D.C., Marais, C, Magadlela, D., 2001. The economic consequences of alien plant invasions: examples of impacts and approaches to sustainable management in South Africa. Environment, Development and Sustainability 3, 145-168.

Versveld, D.B., Le Maitre, D.C., Chapman, R.A., 1998. Alien invading plants and water resources in South Africa: a preliminary assessment. CSIR Division of Water. Environment and Forestry Technology, Stellenbosch.

Woodworth, P., 2006. Working for Water in South Africa, saving the world on a single budget? World Policy Journal Summer 2006.

Wunder, S., 2005. Payments for environmental services: some nuts and bolts. CIFOR Occasional Paper No.42.

Zunckel, K., 2003. Managing and conserving Southern African grasslands with high endemism. Mountain Research and Development 23, 113-118. 